\title{
FEDERAL POWER OVER INTRASTATE RAILROAD RATES.
}

When the United States entered the World War its railroads were not rendering the prompt and efficient service to which the country was entitled and which must be secured if the war were to be waged successfully. The imperative needs of the country forced the Government to take over the railroad systems throughout the length and breadth of the land, to spend large sums of money on repairs and belated improvements, and to operate the railroads as a unit. $\quad$.

The difficulty could not have been met by any appeal to the owners of the roads. They were as patriotic as any body of citizens; but it was simply impossible for them to improve the service adequately. The difficalty was not due to mismanagement; for the operating officials were efficient, and some of them veritable masters of transportation. Nor was it possible by transferring a manager of unusual ability from one railroad to another railroad, with whose problems he was unfamiliar, to secure immediately the necessary improvement in service. Nor would it have been sufficient simply to appropriate funds for the improvement of the railroads. It is true that the railroads were undernourished. For years their incomes had been inadequate, and after I9I4 they could not compete with war industries for the capital which they needed for betterments and extensions. But no appropriation could have immediately given to the railroads adequate equipment, adequate trackage and adequate terminal facilities. It would have taken time as well as money to have built up properly the railroad system of the country-and the Nation could not have waited for the necessary changes nor could it have spared the man-power which would have been taken from the army, the navy and the essential war industries.

The Government did spend, during the war, nearly one and a half billion dollars in building up the railroads; but that expenditure alone would not have brought about the necessary improvement in transportation. It was necessary also, in the emer(II). 
gency, to go further and pool the railroad resources of the country, to disregard the boundaries marked by private ownership and by State lines and to set aside regulations and restrictions which, however, well adapted to other times, were preventing the full use of the railroad facilities which the country then pos. sessed. It was necessary to operate the railroads of the country as a unit, to transfer equipment freely from one railroad to another and to use terminal facilities in common.

And when the war was over and the railroads were returned to their former owners, the American people had learned a great lesson. The Transportation Act of 1920 was legislation of a new type. Instead of simply regulating transportation and forbidding wrongful practices, Congress sought to extend positive aid to the carriers that their roads might be more efficient aids to interstate commerce, and, to that end, it gave them greater freedom of action and it protected them against antagonistic State regulation.

The Act made a tumporary guaranty of incomes to the railroad and express companies and gave very important directions to the commission for the purpose of better assuring to the railroads adequate revenues, and in some cases more than adequate revenues, thereafter. It facilitated the consolidation of railroads and express companies and the pooling of the earnings or traffic of railroads. It gave directions for the joint use of facilities and the establishment of joint rates. After providing that a railroad might not extend or abandon its line or any portion thereof, or issue securities, without the authorization of the commission, it went further and provided that no other authorization should be necessary. These clauses of the Act protected the railroads against unnecessary competition and against the requirement of unnecessary services, regardless of State authorities, and probably regardless of any contracts into which the railroad might have entered. And the Act protected the interstaze business more fully than theretofore by giving to the commission more complete authority to revise any charge or practice which gives any 
undue or unreasonable advantage to intrastate transportation as against interstate transportation.

Congress sought to build up the carriers, to harmonize their relations with each other and with their employees, and to discourage useless or unfair competition between carriers or between interstate and intrastate rates.

Observe that Congress made a departure in legislating as to interstate carricrs instead of simply regulating the interstate transportation of carriers. It dealt with some matters as to interstate carriers which had theretofore been left to the States. This applies not only to the provisions as to extensions, abandonments and securities and the encouragement of co-operation and consolidation as contrasted with competition, but also to the prorisions which apparently direct that carriers be allowed to earn an adequate return from their business as a whole upon their property devoted to transportation as a whole (and not merely an adequate income from their interstate business based upon that portion of their property assignable for purposes of computation to interstate transportation), and it applies to theother provisions which enlarge the power of the commission over intrastate rates and to those provisions which deal with labor disputes. Moreover, Congress authorizes the commission to group railroads and "to establish uniform rates upon competitive traffic which will adequately sustain all the carriers which are engaged in such traffic and which are indispensable to the communities to which they render the service of transportation," although it thereby enables "some of such carriers to receive a net railway operating income substantially and unreasonably in exceśs of a fair return upon the value of their tailway property held for and used in the service of transportation."

In several of the states the railroad commissions have not fully supported the efforts which Congress made through this legislation to improve the railroad systeni of the country, and it has been necessary to appeal to the courts, and finally to the Supreme Court, for aid in enforcing the Transportation Act. 
The leading cases were those from Wisconsin and from New York, both of which were decided by the court of last resort on the twenty-serenth of February, 1922, the opinions being written by Chief Justice Taft. In those cases the Interstate Commerce Commission had ordered railroads which were engaged in interstate transportation to increase their charges for intrastate transportation to correspond to the rates which the Commission had previously established for interstate transportation, and those orders were sustained by the lower Federal courts and by the Supreme Court.

As the Chief Justice pointed out, the Transportation Act imposed upon the Interstate Commerce Commission an affirmative duty to fix rates and to take other important steps to maintain an adequate railway service for the people of the United States. Intrastate rates and the income from them must play an important part in maintaining such a service, and if there is a disparity between interstate and intrastate rates which unduly discriminates againist interstate commerce, the Commission is authorized to end the disparity by directly removing it.

"Congress in its control of its interstate commerce system is secking in the Transportation Act to make the system adequate to the needs of the country by securing for it a reasonable compensatory zeturn for all the work it does. The states are seeking to use that same system for intrastate traffic. That entails large duties and expenditures on the interstate commerce system which may burden it unless compensation is received for the intrastate business reasonably proportionate to that for the interstate business. Congress as the dominant controller of interstate commerce may, therefore, restrain undue limitation of the earning power of the interstate commerce system in doing state work. The affirmative power. of Congress in developing interstate conimerce agencies is clear. In such development, it can impose any reasonable condition on a state's use of interstate carriers for intrastate commerce, it deems necessary or desirable. This is because of the supremacy of the national power . in this field"

The court so declared in the case of the Railroad Commission of $W$ isconsin against the Chicago, Burlington and Quincy . Railroad Company. In the case of the State of New York: 
against the United States, the court went even further and decided that even where the State had a charter contract with the New York Central Railway Company, by which the latter was bound to charge not more than two cents a mile for passenger transportation between Albany and Buffalo, Congress might nevertheless authorize the Interstate Commerce Commission to increase those rates.

"Anything which directly obstructs and thus regulates commerce which is carried on among the states, whether it is state legislation or private contracts between individuals or corporations; should be subject to the power of Congress in the regulation of that commerce."

Two weeks after these decisions were announced, the court decided the Eastern Texas Railroad case, in which it passed upon the power of the Interstate Conimerce Commission to authorize the abandonment of railroad operations. The company, which conducted both interstate and intrastate transportation, had been operated at a loss for several years. Its operating expenses were about $\$ 5,000$ per month greater than its operating revenues, and, in view of the condition of the road because of its operation at a loss it would be necessary in the near future to expend large sums of money upon repairs to roadways, bridges and trestles, if operations were to be continued without "great danger to life and property. .

The Interstate Commerce Commission authorized the company to abandon completely the operation of its line, acting under the provisions of the Transportation Act which empowered the Commission to authorize a railroad subject to the Act to abandon all or any portion of a line of railroad or the operation thereof and authorized the company thereupon to abandon operations zoithout securing any other approval. The State contended that, while the Commission might authorize the company to abandon interstate operations, the Act did not empower it to authorize the railroad to abandon intrastate operations without the consent of the State; and the court of last resort sustained this contention.

The decision was based upon the ground, not expressly 
stated and not discussed by the court, that the Eastern Texas Railroad Company was entirely within the State of Texas, and while all of its outstanding stock had been owned for more than fifteen years by an interstate railroad company, the St. Louis Southwestern, the two companies were distinct entities.

The court declared that

"Interstate and foreign commerce will not be burdened or affected by any shortage in the earnings, nor will any carrier in such commerce have to bear or make good the shortage. It is not as if the road were a branch or extension whose unremunerative operation would or might burden or cripple the main line and thereby affect its utility or service as an artery of interstate and foreign commerce"

The court thus clearly indicated that where the line of track was a part of an interstate railroad system the rule might well be different and an order of the Interstate Commerce Commission authorizing the abandonment of both interstate and intrastate operations be sustained.

These cases, of course, do not dispose of all of the important questions which may arise under the Transportation Act. The court, however, has shown most clearly that Congress may take positive steps in assisting the railroad companies of the country to build up an adequate and efficient transportation system and that the States may not so regulate the intrastate activities of interstate companies as to thwart the efforts of the Federal Government.

Whatever may have been the fact before the era of the steamboat and the locomotive, at the present day steam and electricity have welded commerce into an indiscoluble unit for many practical purposes, and, among these, the most roncnimous is the regulation of the great corporations which operate the interstate railroads of this Nation. Each of these railroads is subject to regulation, not merely by the political state, but by the larger organization which we call human society. .

The banks, in loaning their credit and furnishing the necessary means of constructing the railroad, take no account of the 
legal distinction between interstate and domestic commerce. They loan to the corporation as a unit, and no dollar of the funds which they supply can be allocated by any rule either to interstate or intrastate commerce.

The contractors, engineers, and builders of the road are also unable, in the nature of things, to regulate their operations by any legal distinction between interstate and intrastate commerce. The road that they grade, the ties that they lay, the rails that they nail down, the tunnels they dig, the terminals they erect, the rolling stock that is constructed, are one and all used quite indiscriminately in interstate and domestic commerce and without any legal distinction between them. Mechanically, as financially. the corporation is an indivisible unit.

Then, the road must be operated by labor; and here arises a source of non-governmental regulation which has meant a tremendous burden upon the transportation companies, for labor is highly organized and the corporation deals with its leaders, and these leaders, in prescribing the conditions upon which engineers, firemen, conductors, and brakemen will operate the roads, take no account of any distinction between interstate and intrastate commerce, but, themselves acting as a unit, they render their services to the corporation as a unit-even as the financier and the contractor have done.

The very act of transportation again illustrates the indivisibility from a practical standpoint and not as a legal abstraction of this indivisible thing that we call commerce, for, whether the transportation be wholly within or beyond the State, it runs upon the same rails, it pierces the same tunnels, it employs the same motive power and rolling stock, and the same train moves for one passenger in intrastate commerce and for another in interstate commerce, but, as stated, its propulsion is due to economic and mechanical forces that have no reference to the legal distinction.

If, therefore, the legal distinction which seeks to make $a$ duality of an essential unity does not conform to the nature of these economic forces, it is obvious that our laws are not only 
not in harmony but are lagging behind the economic forces which they are designed to protect and promote.

Fortunately, there is no such rigidity in our political system. Its genius lies in its elasticity and in its adaptability to the ever increasing changes of the most progressive nation in the world. The far-seeing vision of the great Chief Justice realized this in the great case of McCulloch v. Maryland (4 Wheat. 3I6, 4I5), when he said:

"This provision is made in a Constitution intended to endure for ages to come and consequently to be adaptcd to the various crises of human affairs."

In other words, the evolution of the commerce power of the country has been a consistent adaptation of Federal power to those crises, which have been brought about by a mechanical age, which has more profoundly revolutionized human thought and human conditions than any similar change in all the preceding centuries of human existence.

It may be frankly admitted that when the framers of the Constitution provided that "the Congress shall have power to regulate commerce . . . among the several States" they did not have in mind, and in the nature of the case could not have had in mind, the application of this grant of power to the conditions of human society which were about to be profoundly revolutionized. Undoubtedly, they did not intend, as conditions of society then prevailed, to take from the States the primary, regulation of the instrumentalities of commerce. In that day there were very few corporations, and those almost exclusively banking institutions. Indeed, their idea of commerce was largely restricted to sailing vessels which bore merchandise from sthe port of one State to the port of another State. It was not within their contemplation that it would be applied to the conditions of land travel.

A condition in which land travel would be revolutionized by the utilization of steam power was beyond their anticipation, for, when the Constitution was adopted, the only vehicles of com- 
merce outside of the sailing vessel were the horse, the stagecoach, the wagon and the wheelbarrow. More than half a century was to elapse before the first railroad should be commenced, and, while at the very time of the Constitutional Convention a Connecticut Yankee, by the name of Fitch, was experimenting with the steamboat, a full generation was to pass before the prow of the Clcrmont was to divide the waters of the Hudson.

The fact is that in those days the primary regulation of commerce, whether interstate or domestic, could, in the nature of the case, only be for the States. Men lived and died without ever leaving the communities in which they were born. Only a few, and those the wealthy, ever crossed the boundary of the State. Each community was sufficient to itself. Human society was then not so highly organized that a man would feel impoverished if the four corners of the world did not pay tribute to his break- fast table. With few exceptions, men lived upon that which was raised within their immediate vicinity, and even that which they themselves developed. It was still the time when Adam delved and Eve span, and the idea that the Congress should regulate their little commercial enterprises, which were almost wholly intrastate and conducted by individuals, not corporations, was to them inconceivable.

What, then, did the Fathers truly intend by this inspired grant of power?. It is my belief that their true intention was that the new government which they were creating should have a concurrent but a paramount poicer, and that this paramount power would only be exercised when the laws of the States resulted in conflicting regulations to the injury of the Union. The Federal Government was to be the arbiter, or, shall I say, its function was to be that of the governor in a machine.

That this was the immediate application of their far-reaching grant of power is indubitably shown by the fact that for nearly one hundred years the Congress did not regulate iand transportation by any législation, excepting only the grants which it made to the transcontinental railroads shortly after the Civil War. The creation of corporate instrumentalities, the regulation of both 
intrastate and interstate roads, as well as all other regulations of commerce, were primarily the concern of the States, but at all times subject to the paramount authority of the Federal Government to bring them into harmony, in order to avoid the evils of conflicting regulations which had been the chief reason for the creation of the new Nation.

Moreover, in the early days of railroad transportation there were insuperable natural obstacles to the creation of great interstate carriers. Railroads were very primitive affairs-so primitive that for many years after the building of the first railroad it was a subject of earnest and heated discussion among thoughtful men whether the canal or the railroad would be the true method of transportation. Railroads could not then tunnel mountains or cross rivers: of necessity, their operations terminated whenever a natural obstacle was interposed. Thus, between Albany and Buffalo there were, as late as the middle of the nineteenth century, eleven different railroads. The journey to New York was made from Philadelphia to Perth Amboy, where a ship was taken to cross Sandy Hook Bay. The Pennsylvania Railroad ran from Philadelphia to Columbia, and when it finally reached the Allegheny Mountains it necessarily came to a stop, and passengers were taken by a portage road over the Alleghenies and then a new railroad took them to Pittsburgh.

The natural obstacles which thus made for small railroads naturally resulted in their primary and almost exclusive regulation by the States; and the policy of the States was to give almost unrestricted rights of private ownership, for the obvious reason that there was so little faith in the future of American railroads that the States would not contribute out of public funds and the money was contributed by citizens not as a sound financial investment, but practically as a public charity. Thus, the subscrip-. tions to the Pennsyliania Railroad were obtained by begging them from house to house, as though it were a hospital and not a necessary instrumentality of commerce.

All this made for the localization of railroads and for unrestricted rights of private ownership, and it is not unnatural that 
the abuses of such unregulated private ownership led to some of . the blackest chapters in the financial history of our Nation.

During all this time a system of legal regulation was in the slow process of development-not by "the Congress," to which the Constitution had directly intrusted it-but by the judiciary, and notably by the Supreme Court. In this was no usurpation of power, for this system of regulation by judicial veto was derived from the powers of the court as established in the great case of Marbury v. Madison. In other words, the written Constitution would not have been workable if there had not been a balance wheel to keep all the parts in harmonious operation. Thus, the Supreme Court during the full century when the Congress remained inactive in regulating interstate commerce, was building up a great and sagacious system of regulation by a series of decisions which determined what the Nation might do and what the States might do. Of necessity, these decisions were a series of great megations, for the judicial department of the Government had no power to legislate affirmatively. All that it could do was to interpose the negation of its veto when either the Nation invaded the powers of the States, or, more commonly, the States invaded the powers of the Nation. "The power thus exercised was one of extraordinary difficulty and delicacy. It required the Supreme Court to proceed with the very greatest caution from concrete case to concrete case lest it be accused by a usurpation of power of violating the very Constitution which it was sworn to defend.

The court, however, has always recognized that, as human society became more concentrated and complicated, all powers, Federal and State, have a necessary reaction upon each other. With or without political institutions, steam and electricity have woven the commercial intercourse of the country into substantial unity, and this unity is therefore an indivisible unity. Therefore, it was futile for the political government in solving many practical problems to attempt to make any division. All that the Federal Government could do, as the Supreme Court wisely declared, was to recognize as a broad principle that whenever the 
public necessity required that the States should exercise no power whatever, because of its direct and substantial effect upon the current of interstate commerce, the States were powerless, but that in all matters where the effect upon interstate commerce was indirect or insubstantial or where it related to a subject matter as to which a uniform rule was not required for the common good, the States could legisiate as to commerce, subject to the pawer of Congress to. determine otherwise when in its judgment the interests of interstate commerce required a uniform rule.

While this evolution of the Federal power was in progress great changes were taking place in human society, due to the revolutionary results of the utilization of steam power, electricity, and, later, petroleum. The Nation had ceased to be a congeries of little local unities. It had become inextricably interwoven by steel and copper. The local road no longer sufficed to meet the commercial necessities of the Nation. A vast empire to the west of the Alleghenies had been slowly developed. The Civil War had shown the necessity for great corporate instrumentalities which could build roads, not of a few hundred miles, but of many thousands of miles.

The reaction upon our political institutions was necessarily very profound. The conception of commerce and of its unity: became one of which the framers of the Constitution only vaguely dreamed. Slowly it was realized that the prosperity of America depended upon the harvesting machine and the locomotive. The pressure of population in the East, accentuated by the discovery of gold in California, largely delocalized the railroad as a corporate instrumentality. The Government itself entered upon a period of railroad building which has made of America the greatest transportation nation of the world, and without which its present growth and dominant power in the councils of civilization would have been impossible. It chartered great railroad corporations, granting to one, the Union Pacific, an area in land alone greater than the State of New York and with a financial. subventior of $\$ 16,000$ per mile upon lerel ground, of $\$ 32,000$ per mile in the hill country, and $\$ 48,000$ per mile in the moun- 
tains. From 1850 to 1871 the Congress roted to railroads an area of land five times as great as that of the State of Pennsylvania, and thus recognized that America could not grow without a Nation-wide commerce and that the essential instrumentality thereof was a subsidized governmental road.

Unfortunately, the regulation of these roads was still left in private hands subject only to State laws, and the Congress awoke all too slowly to the necessity of Federal regulation.

Those were the days of the Drews, and Jay Goulds, and the railroad wreckers of that class. The evils of such selfish management became intolerable. By unfair and oppressive methods one man was destroyed and another enriched beyond the dreams of avarice. One city waxed great and the other waned. Whole sections-as, for example, the farming interests in the Eastfound themselves paralyzed as by a creeping paralysis, as freight was hauled from the wheat belt of Dakota to London cheaper than was possible for the farmer who tilled the ground only a few miles from the Atlantic seaboard. It became perfectly obvious that unless the evils of private ownership could be abated these great railroad corporations, which were no longer local, but of nation-wide power and influence, would not only go far to destroy the power of the States, not merely by corruption but by the power which they exercised over the property and prosperity of the citizen, but they would even constitute a serious menace to the Nation itself.

It was at that time that the Supreme Court rendered the first of its great decisions with respect to the nature of railroad corporations when, in 1877 , it decided the Granger Cases. They stripped the railroad of its supposed private character, and stamped it as a semi-governmental instrumentality by holding, to use the legal phrase, that it was "impressed with a public use." A full century after the Constitution was adopted Congress, jielding not merely to the so-called granger movement but to the widespread desire of citizens of all classes, passed the first interstate commerce law; and from that time to the passage of the Transportation Act legislation has been a series of advancing 
steps whereby Congress, in behalf of the whole Nation, seeks to end the abuses of transportation and to regulate the commerce of the Nation.

I do not say interstate commerce alone, for commerce had by this time become, through the development of mechanical power and through the growth of great nation-wide corporations, so indivisible for many purposes that it was impossible to divide it into water-tight compartments. To legislate with reference to interstate commerce without assuming an incidental but necessary control over intrastate commerce, had become impracticable with the progress of human society.

While in the mere matter of geography there is still possible a distinction between interstate termini and intrastate termini. yet, in dealing with the instrumentality of commerce, namely, the corporation, and all that it utilizes to make transportation possible, an attempt to allocate any of the functions of any such instrumentality as credit, construction, operation, income, expenditures, to interstate and domestic commerce is a practical impossibility.

Even before the recent cases under the Transportation Act had arisen the Supreme Court had recognized that interstate and intrastate commerce are, for many purposes, so interwoven that their division is impracticable. Thus, in Baltimore \& Ohio Railzuay Co. v. Interstate Commerce Commission (221 U. S. 612), the court said (p. 618):

"But the argument, undoubtedly, involves the consideration that the interstate and intrastate operations of interstate carriers are so interwoven that it is utterly impracticable for them to divide their imployecs in such manner that the duties of those who are engaged in comection with interstate commerce shall be confined to that commerce exclusively. And thus, many employees who have to do with the movement of trains in interstate transportation are, by virtue of practical necessity, also employed in intrastate transportation.

"This consideration, however, lends no support to the contention that the statute is invalid. For there cannot be denied to Congress the effective exercise of its constitutional authority. By virtue of its power to regulate interstate and foreign commerce, Congress may enact. laws for the safeguarding of the persons and property that are transported in that commerce and of those who are employed in transporting them." 
The most notable expression, however, of the indivisibility of commerce for many practical purposes is that suggested in the Minnesota Rate cases (230 U. S. 352), where this court said (pp. 432, 433):

"If the situation has beconic such, by rason of the interblending of the interstate and intrastate operations of interstate carricrs, that adequate regulation of thcir interstate rates camot be maintained without imposing requircments with respect to their intrastate rates which substantially affect the former, it is for Congress to determine, within the limits of its constitutional authority over interstate commerce and its instruments the measure of the regulation it should supply."

The court of last resort has thus recognized repeatedly the fact that, whatever may have been the conditions which existed when the Constitution was adopted and in the early days of this country's history, interstate and intrastate transportation are today in many respects inextricably intermingled, so that the effective regulation of carriers which are engaged in interstate transportation may require also the regulation of the same carriers when they are engaged in intrastate transportation.

As to rates the court of last resort has already spoken in the clear and forcible language of our able Chief Justice. As to railroad co-operation, railroad reorganization, and the many other matters dealt with in the Transportation Act, the court has not yet spoken. But, in view of the position which the court has already taken, when we consider the defects which our railroad system showed in a great emergency, defects which could not have been cured immediately by any effort whatever, it seems improbable that the court will ever declare invalid the great constructive legislation by which Congress in the Transportation Act of 1920 has sought to remedy those defects and to build up 3 transportation system which will meet the great needs of our country both in times of peace and in times of war.

James M. Beck.

Washington, D.C. 